\title{
Design, Synthesis, and Validation of a Branched Flexible Linker for Bioactive Peptides
}

\author{
Martina E. Bowen ${ }^{\dagger}$, Yasunari Monguchi ${ }^{\dagger}$, Rajesh Sankaranarayanan ${ }^{\dagger}$, Josef Vagner $^{\dagger}$, \\ Lucinda J. Begay ${ }^{\dagger}$, Liping $\mathrm{Xu}^{\ddagger}$, Bhumasamudram Jagadish ${ }^{\dagger}$, Victor J. Hruby ${ }^{\dagger}, \ddagger$, Robert $\mathrm{J}$. \\ Gillies $^{\ddagger}$, and Eugene A. Mash ${ }^{\star}, \dagger$ \\ tDepartment of Chemistry, University of Arizona, Tucson, Arizona 85721-0041 \\ ‡Department of Biochemistry and Molecular Biophysics, The Arizona Cancer Center, Tucson, \\ Arizona 85724-5024
}

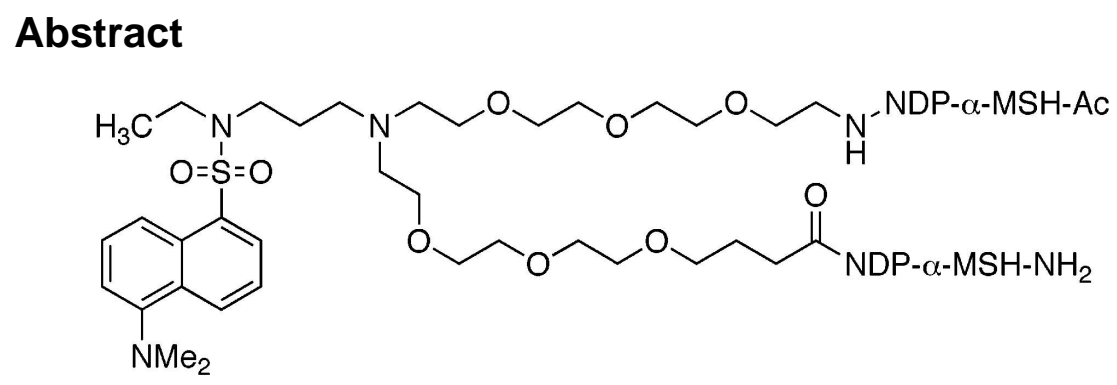

A branched flexible linker that incorporates a fluorescent dansyl moiety was synthesized and used to connect two high affinity NDP-a-MSH ligands or two low affinity MSH(4) ligands. The linker was incorporated into the conjugate by solid-phase synthesis. In vitro biological evaluations showed that potency of binding to the human melanocortin 4 receptor was not diminished for linker-ligand combinations relative to the corresponding ligand alone.

\section{Introduction}

Early detection of many human cancers depends on the availability of nontoxic reagents that can seek out and selectively bind to cancer cells and report their existence and location by noninvasive molecular imaging. $1 \mathrm{We}$ are engaged in a program to develop reagents that target human cancers that presently are difficult to detect, such as melanoma and pancreatic cancer. Our strategy involves linking together reporter moieties and two or more ligands that bind to cell surface receptors that are overexpressed in cancer cells. 2 The resulting multivalent molecules could display enhanced affinity for targeted cells.3

Factors that must be considered in designing linkers for bioactive ligands include the distance that must be spanned, ease of use, biocompatibility, and value-added functionality. The distance that must be spanned between targeted receptors on the cell surface will vary and will often exceed the typical dimensions of small molecules.4 In such cases, several

(C) 2007 American Chemical Society

emash@u.arizona.edu.

Supporting Information Available: General experimental methods for linker synthesis, solid-phase synthesis, competitive binding experiments, and copies of the ${ }^{1} \mathrm{H}$ NMR and ${ }^{13} \mathrm{C}$ NMR spectra of compounds $\mathbf{7 , 9 , 1 2 , 1 4}$, and 17. This material is available free of charge via the Internet at http://pubs.acs.org. 
small molecule linkers connected in series will be necessary to span the distance between receptors.

For peptide ligands, linkers should terminate in an amine and a carboxylic acid to facilitate incorporation by solid-phase synthesis. Each linker employed in the assembly of compounds that contain multiple copies of one ligand, or ligands of multiple types, must be validated as noninterfering with the binding of the ligands of interest. Both rigid linkers5 and flexible linkers6 are in development. The use of water-soluble and biocompatible poly(ethylene oxide) oligomers (PEGs) as linkers is well established.7 While several linear PEGs that terminate in amine and carboxylic acid functional groups are commercially available, 8 to the best of our knowledge, branched PEG oligomers such as $\mathbf{1}$ that are akin to lysine have not been reported.9 Such branching would afford the opportunity to attach, in addition to peptide ligands, fluorescent moieties for imaging or therapeutic moieties for targeted treatment of diseased cells. Linkers such as $\mathbf{1}$ are modular and can be connected together to bridge larger distances and/or to mix ligand, imaging, and therapeutic moieties on one chain. We report herein a synthesis of a fluorescent derivative of $\mathbf{1}$, attachment of "high-affinity" NDP-a-MSH or "low-affinity" MSH(4) variants of a-melanocyte stimulating hormone10 to produce compounds $\mathbf{2}$ and $\mathbf{3}$, as well as control compounds $\mathbf{4}$ and $\mathbf{5}$, and evaluation of the bioactivities of these peptides.<smiles>NCCCN(CCOCCOCCOCCN)CCOCCOCCOCCCC(=O)O</smiles><smiles>[R7]NCCOCCOCCOCCN(CCCN(CC)S(=O)(=O)c1cccc2c(N(C)C)cccc12)CCOCCOCCOCCCC([R2])=O</smiles>

\section{Results and Discussion}

A synthesis of the fluorescent derivative $\mathbf{1 7}$ of linker 1 is depicted in Scheme 1. Known amine 611 was allowed to react with acrylonitrile in methanol, producing nitrile $\mathbf{7}$ in $80 \%$ yield. Separately, the sodium salt derived from tri(ethylene glycol) was allowed to react with known iodide 812 in THF, giving alcohol 9 in $65 \%$ yield. This alcohol was subjected to Swern oxidation to produce the unstable aldehyde 10. Reductive coupling of amine $\mathbf{7}$ and aldehyde $\mathbf{1 0}$ using sodium triacetoxyborohydride gave nitrile 11. This compound, which 
possesses the skeleton of linker 1, was subjected to partial hydrolysis of the ortho ester and subsequently to transesterification using potassium carbonate in dry methanol to give ester $\mathbf{1 2}$ in 57\% yield from alcohol $\mathbf{9}$. Reductive ethylation of the nitrile moiety of $\mathbf{1 2}$ was accomplished by the method of Sajiki et al.13 Reaction of $\mathbf{1 3}$ with dansyl chloride afforded sulfonamide 14 in $47 \%$ yield from 12. Acid-catalyzed removal of the Boc group, saponification of the methyl ester, and protection of the free amine as the trifluoroacetamide $(\mathbf{1 4} \rightarrow \mathbf{1 5} \rightarrow \mathbf{1 6} \rightarrow \mathbf{1 7})$ was effected in $93 \%$ yield over the three steps.

Compound $\mathbf{1 7}$ incorporates a $\gamma$-alkoxy acid terminus instead of a $\beta$-alkoxy acid moiety 7,8 to preclude unwanted $\beta$-elimination processes. $N$-Ethylation prior to introduction of the dansyl moiety clears the linker of an acidic proton that could interfere with solid-phase synthesis and/or make the fluorescence properties of the molecule $\mathrm{pH}$ sensitive.14

The solid-phase synthesis of compound $\mathbf{2}$ consisting of two NDP-a-MSH ligands connected in a head-to-tail fashion by the fluorescent linker is depicted in Scheme 2 and is presented below. Also shown in Scheme 2 and presented is the synthesis of control compound 4 consisting of one NDP-a-MSH ligand connected at the peptide $N$-terminus through the carboxylate of the fluorescent linker.

NDP-a-MSH10 was constructed on Rink amide Tentagel S resin (18, initial loading 0.17 $\mathrm{mmol} / \mathrm{g}$ ). 15 The product resin 19 retained all side-chain protecting groups. Acid 17 was coupled to the $\mathrm{N}$-terminus of $\mathbf{1 9}$ to give resin 20. The $\mathrm{N}$-trifluoroacetamide protecting group was cleaved by treatment with $15 \%$ hydrazine and $15 \%$ methanol in THF, and the resulting resin $\mathbf{2 1}$ was split into two portions. For the synthesis of $\mathbf{2}$, the free amine group of resin $\mathbf{2 1}$ was coupled with Fmoc-valine, and solid-phase synthesis continued to completion of the second NDP-a-MSH ligand, giving resin 22. The $\mathrm{N}$-terminus was then capped by $\mathrm{N}$ acetylation, producing resin $\mathbf{2 3}$. For the synthesis of control 4, resin 21 was terminally $N$ acetylated to give resin $\mathbf{2 4}$. Simultaneous side-chain deprotection and cleavage of the peptides from resins $\mathbf{2 3}$ and $\mathbf{2 4}$ was effected using a mixture of trifluoroacetic acid, 1,2ethanedithiol, thioanisole, and water (91/3/3/3), producing the desired compounds 2 and 4. Compounds $\mathbf{3}$ and $\mathbf{5}$ incorporating the MSH(4) ligand10 were similarly prepared.

Compounds 2-5 were purified by reversed-phase $\mathrm{C}_{18}$ preparative HPLC and were characterized by ESI-MS and MALDI-TOF. Mass spectral and HPLC characterization data are given in Table 1. Ligand binding was evaluated using a previously described lanthanidebased binding assay (see the Supporting Information).16 HEK293 cells overexpressing the human melanocortin 4 receptor (hMC4R) were used to assess ligand binding. 17 Table 2 lists the $\mathrm{IC}_{50}$ values (averaged over $n$ experiments) for the ligands NDP-a-MSH and MSH(4), as well as for compounds $\mathbf{2 - 5}$. Compound $\mathbf{2}$ bound with a 2 -fold higher affinity as compared to $\mathbf{4}$, possibly a statistical effect as $\mathbf{2}$ contains two NDP-a-MSH ligands to one for 4.

Synergistic affects are absent because the ligands in $\mathbf{2}$ are too far apart for enhanced activity from a proximity affect, $2,5 \mathrm{c}$ but not far enough apart for enhanced binding due to receptor cross-linking. However, this statistical effect disappeared for compounds $\mathbf{3}$ and $\mathbf{5}$ that contain the weaker binding MSH(4) ligand. Compounds 2-5 were all slightly more potent binders at the hMC4 receptor when compared with the corresponding parental ligands. Thus, it appears that this linker does not interfere with binding of either the NDP-a-MSH ligand or the MSH(4) ligand at the $\mathrm{hMC} 4$ receptor.

\section{Conclusion}

This paper describes the synthesis of a branched flexible linker that terminates in amino and carboxylic acid functional groups to facilitate incorporation of the linker into multimeric peptide ligand constructs by solid-phase synthesis. The backbone of the linker is a hybrid 
poly(ethylene oxide)/ethylene imine that affords water solubility and biocompatibility to the linker. The branching of the linker permits incorporation of moieties for imaging and/or therapeutic use. In the present work, a fluorescent dansyl group was incorporated. The carboxyl terminus of the linker is based on a $\gamma$-alkoxybutanoic acid substructure rather than the common $\beta$-alkoxypropionic acid substructure. This prevents unwanted $\beta$-elimination reactions from interfering with synthetic manipulations. The utility of this linker was demonstrated by synthesis of compounds containing one or two copies of ligands targeted to the human melanocortin 4 receptor. In vitro binding studies established the noninterference of the linker with ligand binding to this receptor.

\section{Experimental}

\section{tert-Butyl 1-Cyano-6,9,12-trioxa-3,15-diazahexadecanoate (7)}

To a solution of $6(4.34 \mathrm{~g}, 14.8 \mathrm{mmol})$ in $\mathrm{MeOH}(9 \mathrm{~mL})$ was added acrylonitrile $(1.56 \mathrm{~mL}$, $1.26 \mathrm{~g}, 23.7 \mathrm{mmol}$ ) dropwise over $12 \mathrm{~min}$. After $19 \mathrm{~h}$, the mixture was concentrated in vacuo, and the residue was purified by flash column chromatography on silica gel (EtOAc/ $\mathrm{MeOH}, 10: 1 \rightarrow 2: 1)$ to give $7(4.07 \mathrm{~g}, 11.8 \mathrm{mmol}, 80 \%)$ as a colorless oil: analytical TLC on silica gel, 3:1 EtOAc/MeOH, $R_{f}=0.31$ (ninhydrin); ${ }^{1} \mathrm{H} \mathrm{NMR}\left(\mathrm{CDCl}_{3}\right) \delta 1.39(9 \mathrm{H}, \mathrm{s})$, $2.49(2 \mathrm{H}, \mathrm{t}, J=6.8 \mathrm{~Hz}), 2.78(2 \mathrm{H}, \mathrm{t}, J=5.1 \mathrm{~Hz}), 2.90(2 \mathrm{H}, \mathrm{t}, J=6.8 \mathrm{~Hz}), 3.26(2 \mathrm{H}, \mathrm{m}), 3.49$ $(2 \mathrm{H}, \mathrm{t}, J=5.1 \mathrm{~Hz}), 3.54-3.82(10 \mathrm{H}, \mathrm{m}), 5.22(1 \mathrm{H}, \mathrm{br} \mathrm{s}) ;{ }^{13} \mathrm{C} \mathrm{NMR}\left(\mathrm{CDCl}_{3}\right) \delta 18.5,28.4$, 40.3, 45.0, 48.5, 70.1, 70.2, 70.3, 70.4, 79.0, 118.6, 156.0 (two signals could not be located because of their overlaps with other signals); HRMS (FAB ${ }^{+}$, NBA) calcd for $\mathrm{C}_{16} \mathrm{H}_{32} \mathrm{~N}_{3} \mathrm{O}_{5}$ $(\mathrm{M}+\mathrm{H})^{+}$346.2342, found 346.2330.

\section{2-(4-Methyl-2,6,7-trioxabicyclo[2.2.2]octan-1-yl)-3,6,9-trioxatridecan-1-ol (9)}

To NaH (499 mg, $20.8 \mathrm{mmol}$ ) was added a solution of tri(ethylene glycol) $(4.73 \mathrm{~g}, 4.20 \mathrm{~mL}$, $31.5 \mathrm{mmol})$ in THF $(20 \mathrm{~mL})$ dropwise. After $30 \mathrm{~min}$, a solution of $\mathbf{8}(3.10 \mathrm{~g}, 10.4 \mathrm{mmol})$ in THF $(10 \mathrm{~mL})$ was added dropwise. The mixture was heated to reflux, and after $2 \mathrm{~h}$, the reaction was quenched with $\mathrm{H}_{2} \mathrm{O}(10 \mathrm{~mL})$. The mixture was extracted with $\mathrm{CH}_{2} \mathrm{Cl}_{2}(20 \mathrm{~mL}$ $\times 5)$, and the combined organic layers were dried $\left(\mathrm{MgSO}_{4}\right)$, filtered, and concentrated in vacuo. The residue was purified by flash column chromatography on silica gel (hexanes/ EtOAc/Et $3 \mathrm{~N}, 29: 67: 4)$ to give $\mathbf{9}(2.18 \mathrm{~g}, 6.80 \mathrm{mmol}, 65 \%)$ as a pale yellow oil: analytical TLC on silica gel, 12:1 EtOAc/MeOH, $R_{f}=0.42$ (anisaldehyde); ${ }^{1} \mathrm{H}$ NMR $\left(\mathrm{CDCl}_{3}\right) \delta 0.76$ $(3 \mathrm{H}, \mathrm{s}), 1.69(4 \mathrm{H}, \mathrm{m}), 2.57(1 \mathrm{H}, \mathrm{t}, J=6.8 \mathrm{~Hz}), 3.43(2 \mathrm{H}, \mathrm{m}), 3.51-3.68(12 \mathrm{H}, \mathrm{m}), 3.84(6 \mathrm{H}$, s); ${ }^{13} \mathrm{C} \mathrm{NMR}\left(\mathrm{CDCl}_{3}\right) \delta 14.5,23.4,30.2,33.2,61.7,69.8,70.4,70.6,70.6,70.9,72.5,72.5$, 109.0; HRMS (FAB ${ }^{+}, \mathrm{NBA}$ ) calcd for $\mathrm{C}_{15} \mathrm{H}_{29} \mathrm{O}_{7}(\mathrm{M}+\mathrm{H})^{+}$321.1913, found 321.1907.

\section{1-tert-Butyl 27-Methyl 14-(2-Cyanoethyl)-5,8,11,17,20,23-hexaoxa-2,14- diazaheptacosanedioate (12)}

To a solution of oxalyl chloride $(856 \mu \mathrm{L}, 9.81 \mathrm{mmol})$ in $\mathrm{CH}_{2} \mathrm{Cl}_{2}(28 \mathrm{~mL})$ at $-78{ }^{\circ} \mathrm{C}$ was added a solution of DMSO $(1.39 \mathrm{~mL}, 19.6 \mathrm{mmol})$ in $\mathrm{CH}_{2} \mathrm{Cl}_{2}(7 \mathrm{~mL})$ over $5 \mathrm{~min}$. After 3 min, a solution of $9(2.86 \mathrm{~g}, 8.92 \mathrm{mmol})$ in $\mathrm{CH}_{2} \mathrm{Cl}_{2}(10 \mathrm{~mL})$ was added through a cannula over $7 \mathrm{~min}$. After $15 \mathrm{~min}, \mathrm{Et}_{3} \mathrm{~N}(6.22 \mathrm{~mL}, 44.6 \mathrm{mmol})$ was added over $3 \mathrm{~min}$, and after 75 min, the cooling bath was removed. After $10 \mathrm{~min}, \mathrm{H}_{2} \mathrm{O}(35 \mathrm{~mL})$ and $\mathrm{CH}_{2} \mathrm{Cl}_{2}(100 \mathrm{~mL})$ were added. The layers were separated, and the aqueous layer was extracted with $\mathrm{CH}_{2} \mathrm{Cl}_{2}(150$ $\mathrm{mL} \times 2)$. The combined organic layers were dried $\left(\mathrm{MgSO}_{4}\right)$, filtered, and concentrated in vacuo. The residue was mixed with $7(3.35 \mathrm{~g}, 9.70 \mathrm{mmol})$, and the mixture was dissolved in 1,2-dichloroethane $(100 \mathrm{~mL})$. To the solution at $0{ }^{\circ} \mathrm{C}$ was added $\mathrm{NaBH}(\mathrm{OAc})_{3}(3.03 \mathrm{~g}, 14.3$ $\mathrm{mmol})$ in one portion. After $3 \mathrm{~h}$, additional $\mathrm{NaBH}(\mathrm{OAc})_{3}(377 \mathrm{mg}, 1.78 \mathrm{mmol})$ was added. After $40 \mathrm{~min}, \mathrm{H}_{2} \mathrm{O}(35 \mathrm{~mL})$ was added, and the layers were separated. The aqueous layer was extracted with $\mathrm{CH}_{2} \mathrm{Cl}_{2}(150 \mathrm{~mL} \times 3)$, and the organic layers were combined, dried $\left(\mathrm{MgSO}_{4}\right)$, filtered, and concentrated in vacuo. The residue was dissolved in $\mathrm{MeOH}$ (80 
$\mathrm{mL})-\mathrm{H}_{2} \mathrm{O}(1 \mathrm{~mL})$. To the solution was added $p-\mathrm{TsOH} \cdot \mathrm{H}_{2} \mathrm{O}(899 \mathrm{mg}, 4.46 \mathrm{mmol})$, and after $4.5 \mathrm{~h}$, additional $p$ - $\mathrm{TsOH} \cdot \mathrm{H}_{2} \mathrm{O}(170 \mathrm{mg}, 0.892 \mathrm{mmol})$ was added. After $19 \mathrm{~h}$, saturated aqueous $\mathrm{NaHCO}_{3}(5 \mathrm{~mL})$ was added, and the mixture was concentrated in vacuo to ca. 15 $\mathrm{mL}$. EtOAc $(300 \mathrm{~mL})$ and brine $(20 \mathrm{~mL})$ were added, and the layers were separated. The aqueous layer was extracted with EtOAc $(300 \mathrm{~mL})$, and the combined organic layers were dried $\left(\mathrm{MgSO}_{4}\right)$, filtered, and concentrated in vacuo. The residue was dissolved in distilled $\mathrm{MeOH}(100 \mathrm{~mL})$, and $\mathrm{K}_{2} \mathrm{CO}_{3}(2.10 \mathrm{~g}, 15.2 \mathrm{mmol})$ was added to the solution at $\mathrm{rt}$ in one portion. After $1.5 \mathrm{~h}$, the mixture was cooled to $0{ }^{\circ} \mathrm{C}$, and EtOAc $(140 \mathrm{~mL})$ and saturated aqueous $\mathrm{NH}_{4} \mathrm{Cl}(140 \mathrm{~mL})$ were added. The layers were separated, and the organic layer was washed with brine $(20 \mathrm{~mL})$. The combined aqueous layers were extracted with EtOAc (200 $\mathrm{mL} \times 2)$, and the organic layers were combined, dried $\left(\mathrm{MgSO}_{4}\right)$, filtered, and concentrated in vacuo. The residue was purified by flash column chromatography on silica gel (EtOAc/ $\mathrm{MeOH}, 30: 1 \rightarrow 7: 1)$ to give $\mathbf{1 2}(2.95 \mathrm{~g}, 5.11 \mathrm{mmol}, 57 \%$ from 9$)$ as a pale yellow oil: analytical TLC on silica gel, 5:1 EtOAc/MeOH, $\left.R_{f}\right)=0.47$ (ninhydrin); ${ }^{1} \mathrm{H} \mathrm{NMR}\left(\mathrm{CDCl}_{3}\right) \delta$ $1.41(9 \mathrm{H}, \mathrm{s}), 1.89(2 \mathrm{H}, \mathrm{m}), 2.37(2 \mathrm{H}, \mathrm{d}, J=7.3 \mathrm{~Hz}), 2.49(2 \mathrm{H}, \mathrm{br} \mathrm{m}), 2.76(4 \mathrm{H}, \mathrm{br}, \mathrm{m}), 2.95$ $(2 \mathrm{H}, \mathrm{br} \mathrm{m}), 3.28(2 \mathrm{H}, \mathrm{m}), 3.44-3.88(27 \mathrm{H}, \mathrm{m}), 5.05(1 \mathrm{H}, \mathrm{br} \mathrm{s}) ;{ }^{13} \mathrm{C} \mathrm{NMR}\left(\mathrm{CDCl}_{3}\right) \delta 16.3$, $24.9,28.4,30.7,40.3,50.9,51.5,54.0,54.0,68.7,70.1,70.2,70.4,70.4,70.5,70.5,79.1$, $119.3,156.0,173.9$ (five signals could not be located because of their overlaps with other signals); HRMS (FAB ${ }^{+}, \mathrm{NBA}$ ) calcd for $\mathrm{C}_{27} \mathrm{H}_{52} \mathrm{~N}_{3} \mathrm{O}_{10}(\mathrm{M}+\mathrm{H})^{+}$578.3653, found 578.3660.

\section{1-tert-Butyl 27-Methyl 14-[3-( $N$-Ethyl- $N$-dansyl)aminopropyl]-5,8,11,17,20,23-hexaoxa-2,14- diazaheptacosanedioate (14)}

To a solution of $12(338 \mathrm{mg}, 0.585 \mathrm{mmol})$ in $\mathrm{MeOH}(1.8 \mathrm{~mL})$ was added $5 \% \mathrm{Rh} / \mathrm{C}(\mathrm{N}$. E. Chemcat, Tokyo, Japan, $101 \mathrm{mg}$ ), and the system was sealed with a septum. $\mathrm{EtNH}_{2}$ solution $(2 \mathrm{M})$ in $\mathrm{MeOH}(2.93 \mathrm{~mL}, 5.85 \mathrm{mmol})$ was added, and after $30 \mathrm{~min}$, the air inside was replaced with hydrogen (balloon) by three vacuum $/ \mathrm{H}_{2}$ cycles and additional $2 \mathrm{M} \mathrm{EtNH}$ solution in $\mathrm{MeOH}(1.47 \mathrm{~mL}, 2.93 \mathrm{mmol})$ was added. After $21 \mathrm{~h}$, the mixture was passed through a Celite pad, and the pad was washed with $\mathrm{MeOH}(100 \mathrm{~mL})$. The combined filtrates were concentrated in vacuo to give a $6: 4$ mixture $(331 \mathrm{mg})$ of monoethylated amine and unethylated amine. The amines mixture was dissolved in $\mathrm{MeOH}(3.2 \mathrm{~mL})$, and $\mathrm{MeCN}$ (143 $\mu \mathrm{L}, 2.73 \mathrm{mmol})$ and $5 \% \mathrm{Rh} / \mathrm{C}(97.8 \mathrm{mg})$ were added. The air inside the flask was replaced with $\mathrm{H}_{2}$ (balloon) as described above and stirred at rt. After $21 \mathrm{~h}$, the mixture was passed through a Celite pad, and the pad was washed with $\mathrm{MeOH}(100 \mathrm{~mL})$. The combined filtrates were concentrated in vacuo to give a mixture $(328 \mathrm{mg}$ ) of monoethylated amine, diethylated amine, and unethylated amine in a ratio of 87:4:9, respectively. The amines mixture was dissolved in $\mathrm{MeOH}(3.0 \mathrm{~mL})$, and $\mathrm{MeCN}(134 \mu \mathrm{L}, 2.57 \mathrm{mmol})$ and $5 \% \mathrm{Rh} / \mathrm{C}(93.9 \mathrm{mg})$ were added. The air inside the flask was replaced with $\mathrm{H}_{2}$ (balloon) as described above and the mixture stirred at rt. After $22 \mathrm{~h}$, the mixture was passed through a Celite pad, and the pad was washed with $\mathrm{MeOH}(100 \mathrm{~mL})$. The combined filtrates were concentrated in vacuo to give a mixture of monoethylated amine, diethylated amine, and unethylated amine (306 mg) in a ratio of 87:9:4, respectively. Proton NMR data for the monoethylated amine 13: ${ }^{1} \mathrm{H}$ $\operatorname{NMR}\left(\mathrm{CDCl}_{3}\right) \delta 1.08(3 \mathrm{H}, \mathrm{t}, J=6.8 \mathrm{~Hz}), 1.38(9 \mathrm{H}, \mathrm{s}), 1.62(2 \mathrm{H}$, quin, $J=6.8 \mathrm{~Hz}), 1.84(2 \mathrm{H}$, quin, $J=6.8 \mathrm{~Hz}), 2.34(2 \mathrm{H}, \mathrm{t}, J=6.8 \mathrm{~Hz}), 2.54(2 \mathrm{H}, \mathrm{t}, J=6.8 \mathrm{~Hz}), 2.60-2.67(8 \mathrm{H}, \mathrm{m}), 3.25$ $(4 \mathrm{H}, \mathrm{m}), 3.41-3.61(23 \mathrm{H}, \mathrm{m}), 5.14(1 \mathrm{H}, \mathrm{br} \mathrm{s})$. The mixture of amines was dissolved in a mixture of $\mathrm{CH}_{2} \mathrm{Cl}_{2}(15 \mathrm{~mL})$ and THF $(1 \mathrm{~mL})$, and dansyl chloride $(170 \mathrm{mg}, 0.629 \mathrm{mmol})$ was added. After $1 \mathrm{~h}, \mathrm{Et}_{3} \mathrm{~N}(33.8 \mu \mathrm{L}, 0.242 \mathrm{mmol})$ was added, and after $14.5 \mathrm{~h}$, additional $\mathrm{Et}_{3} \mathrm{~N}(33.8 \mu \mathrm{L}, 0.242 \mathrm{mmol})$ was added. After $1 \mathrm{~h}$, EtOAc $(150 \mathrm{~mL})$ and $\mathrm{H}_{2} \mathrm{O}(50 \mathrm{~mL})$ were added, and the layers were separated. The organic layer was washed with brine $(10 \mathrm{~mL})$, and the combined aqueous layers were extracted with EtOAc $(150 \mathrm{~mL})$. The organic layers were combined, dried $\left(\mathrm{MgSO}_{4}\right)$, filtered, and concentrated in vacuo. The residue was purified by flash column chromatography on silica gel $\left(\mathrm{CH}_{2} \mathrm{Cl}_{2} / \mathrm{MeOH}, 30: 1 \rightarrow 12: 1\right)$ to give $\mathbf{1 4}$ (212 $\mathrm{mg}, 0.251 \mathrm{mmol}, 47 \%$ from 12) as a light green oil. Data for 14: analytical TLC on silica 
gel, 10:1 $\mathrm{CH}_{2} \mathrm{Cl}_{2} / \mathrm{MeOH}, R_{f}=0.30$ (longwave UV); ${ }^{1} \mathrm{H} \mathrm{NMR}\left(\mathrm{CDCl}_{3}\right) \delta 1.04(3 \mathrm{H}, \mathrm{t}, J=6.8$ $\mathrm{Hz}), 1.40(9 \mathrm{H}, \mathrm{s}), 1.60(2 \mathrm{H}$, br quin, $J=6.8 \mathrm{~Hz}), 1.86(2 \mathrm{H}$, quin, $J=6.8 \mathrm{~Hz}), 2.36(4 \mathrm{H}, \mathrm{m})$, $2.57(4 \mathrm{H}, \mathrm{m}), 2.84(6 \mathrm{H}, \mathrm{s}), 3.24-3.36(6 \mathrm{H}, \mathrm{m}), 3.40-3.57(24 \mathrm{H}, \mathrm{m}), 3.63(3 \mathrm{H}, \mathrm{s}), 5.02(1 \mathrm{H}$, br s), $7.13(1 \mathrm{H}, \mathrm{d}, J=7.3 \mathrm{~Hz}), 7.44-7.52(2 \mathrm{H}, \mathrm{m}), 8.13(1 \mathrm{H}, \mathrm{d}, J=7.3 \mathrm{~Hz}), 8.24(1 \mathrm{H}, \mathrm{d}, J=$ $8.5 \mathrm{~Hz}), 8.48(1 \mathrm{H}, \mathrm{d}, J=8.5 \mathrm{~Hz}) ;{ }^{13} \mathrm{C}$ NMR $\left(\mathrm{CDCl}_{3}\right) \delta 13.6,24.8,26.1,28.4,30.7,40.3$, $41.5,44.5,45.4,51.5,52.5,53.7,69.6,70.0,70.1,70.2,70.3,70.5,70.5,79.1,115.0,119.6$, 123.0, 127.8, 129.4, 130.0, 130.0, 135.4, 151.6, 155.9, 173.9 (seven signals could not be located because of their overlaps with other signals); HRMS (FAB $\left.{ }^{+}, \mathrm{MIX}\right)$ calcd for $\mathrm{C}_{41} \mathrm{H}_{71} \mathrm{~N}_{4} \mathrm{O}_{12} \mathrm{~S}(\mathrm{M}+\mathrm{H})^{+}$843.4789, found 843.4777.

\section{4-[3-( $N$-Ethyl- $N$-dansyl)aminopropyl]-25-trifluoroacetylamino-5,8,11,17,20,23-hexaoxa-14- azapentacosanoic Acid (17)}

To a solution of $\mathbf{1 4}(212 \mathrm{mg}, 0.251 \mathrm{mmol})$ in EtOAc $(6 \mathrm{~mL})-\mathrm{MeOH}(2 \mathrm{~mL})$ at $\mathrm{rt}$ was added $2 \mathrm{M} \mathrm{HCl}$ in $\mathrm{Et}_{2} \mathrm{O}$ solution $(5.00 \mathrm{~mL}, 10.0 \mathrm{mmol})$. After $2 \mathrm{~h}$, additional $2 \mathrm{M} \mathrm{HCl}$ in $\mathrm{Et}_{2} \mathrm{O}$ solution $(7.50 \mathrm{~mL}, 15.0 \mathrm{mmol})$ was added, and after an additional $2 \mathrm{~h}$, the mixture was concentrated in vacuo. The residue was coevaporated with $\mathrm{MeOH}(5 \mathrm{~mL} \times 3)$. Analytical TLC on silica gel, $10: 1 \mathrm{CH}_{2} \mathrm{Cl}_{2} / \mathrm{MeOH}, R_{f}=0.11$ or 5:1 $\mathrm{CH}_{2} \mathrm{Cl}_{2} / \mathrm{MeOH}, R_{f}=0.32$ (longwave UV). To the residue were added $\mathrm{MeOH}(4 \mathrm{~mL})$, THF $(2 \mathrm{~mL})$, and $2 \mathrm{M} \mathrm{NaOH}$ ( $2.51 \mathrm{~mL}, 5.02 \mathrm{mmol})$ successively. After $4 \mathrm{~h}$, additional $2 \mathrm{M} \mathrm{NaOH}(1.26 \mathrm{~mL}, 2.51 \mathrm{mmol})$ was added. After $3 \mathrm{~h}$, the mixture was acidified to $\mathrm{pH} 4$ with $2 \mathrm{M} \mathrm{HCl}, n-\mathrm{BuOH}(80 \mathrm{~mL})$ and brine $(5 \mathrm{~mL})$ were added, and the layers were separated. The organic layer was washed with brine $(5 \mathrm{~mL})$, and the combined aqueous layers were extracted with $n-\mathrm{BuOH}(80 \mathrm{~mL} \times$ $3)$. The organic layers were combined, dried $\left(\mathrm{Na}_{2} \mathrm{SO}_{4}\right)$, filtered, and concentrated in vacuo. Analytical TLC on silica gel, 5:1 $\mathrm{CH}_{2} \mathrm{Cl}_{2} / \mathrm{MeOH}, R_{f}=0.07$ (longwave UV). The residue was dissolved in $\mathrm{MeOH}(15 \mathrm{~mL})$, and $\mathrm{Et}_{3} \mathrm{~N}(176 \mu \mathrm{L}, 1.26 \mathrm{mmol})$ and $\mathrm{CF}_{3} \mathrm{CO}_{2} \mathrm{Et}(150 \mu \mathrm{L}$, $1.26 \mathrm{mmol}$ ) were added. After $18 \mathrm{~h}$, the mixture was concentrated in vacuo. EtOAc (100 $\mathrm{mL}$ ) and brine $(10 \mathrm{~mL})$ were added, and the layers were separated. The aqueous layer was extracted with EtOAc $(100 \mathrm{~mL} \times 3)$, and the combined organic layers were dried $\left(\mathrm{Na}_{2} \mathrm{SO}_{4}\right)$, filtered, and concentrated in vacuo. The residue was separated by PLC $\left(\mathrm{CHCl}_{3} / \mathrm{MeOH}, 6: 1\right.$, developed five times, longwave UV), and the silica gel containing product was collected in a flash column and eluted with $\mathrm{CHCl}_{3} / \mathrm{MeOH}(4: 1 \rightarrow 3: 1)$. The eluent was concentrated in vacuo, EtOAc $(100 \mathrm{~mL})$ and $2 \mathrm{M} \mathrm{HCl}(30 \mathrm{~mL})$ were added to the residue, and the layers were separated. The organic layer was discarded, and the aqueous layer was adjusted to $\mathrm{pH}$ 6 with $2 \mathrm{M} \mathrm{NaOH}$ and extracted with EtOAc $(100 \mathrm{~mL})$. The organic layer was washed with brine $(10 \mathrm{~mL})$, and the combined aqueous layer was extracted with EtOAc $(300 \mathrm{~mL} \times 2)$. The organic layers were dried $\left(\mathrm{Na}_{2} \mathrm{SO}_{4}\right)$ and concentrated in vacuo. $\mathrm{CHCl}_{3}(10 \mathrm{~mL})$ was added to the residue, passed through a cotton-packed pasteur pipet, and washed with $\mathrm{CHCl}_{3}$ $(20 \mathrm{~mL})$. The filtrate was concentrated in vacuo to give $\mathbf{1 7}(192 \mathrm{mg}, 0.233 \mathrm{mmol}, 93 \%)$ as a light green oil: analytical TLC on silica gel, 5: $1 \mathrm{CH}_{2} \mathrm{Cl}_{2} / \mathrm{MeOH}, R_{f}=0.35$ (longwave UV); $\lambda_{\max } 343 \mathrm{~nm}(\varepsilon=4500, \mathrm{DMSO}) ;{ }^{1} \mathrm{H} \mathrm{NMR}\left(\mathrm{CDCl}_{3}\right) \delta 0.99(3 \mathrm{H}, \mathrm{t}, J=6.8 \mathrm{~Hz}), 1.85(2 \mathrm{H}$, quin, $J=6.4 \mathrm{~Hz}), 2.03(2 \mathrm{H}, \mathrm{br} \mathrm{m}), 2.38(2 \mathrm{H}, \mathrm{t}, J=6.4 \mathrm{~Hz}), 2.85(6 \mathrm{H}, \mathrm{s}), 3.04(2 \mathrm{H}, \mathrm{br} \mathrm{m})$, $3.15(4 \mathrm{H}, \mathrm{br} \mathrm{m}), 3.29-3.38(4 \mathrm{H}, \mathrm{m}), 3.48-3.61(22 \mathrm{H}, \mathrm{m}), 3.81(4 \mathrm{H}, \mathrm{m}), 7.15(1 \mathrm{H}, \mathrm{d}, J=7.3$ $\mathrm{Hz}), 7.46-7.55(2 \mathrm{H}, \mathrm{m}), 7.57(1 \mathrm{H}, \mathrm{br} \mathrm{s}), 8.11(1 \mathrm{H}, \mathrm{d}, J=7.3 \mathrm{~Hz}), 8.21(1 \mathrm{H}, \mathrm{d}, J=8.5 \mathrm{~Hz})$, $8.50(1 \mathrm{H}, \mathrm{d}, J=8.5 \mathrm{~Hz}) ;{ }^{13} \mathrm{C}$ NMR $\left(\mathrm{CDCl}_{3}\right) \delta 13.4,23.3,24.9,31.2,39.6,41.8,44.0,45.4$, $52.3,52.8,53.2,66.2,66.4,68.6,70.1,70.2,70.2,70.3,70.4,70.5,70.7,115.2,115.9$ (q, $J=$ $288 \mathrm{~Hz}), 119.3,123.2,128.1,129.4,130.0,130.3,135.0,151.8,157.3(\mathrm{q}, J)=37 \mathrm{~Hz}), 176.2$ (three signals could not be located because of their overlaps with other signals); ${ }^{19} \mathrm{~F}$ NMR $\left(\mathrm{CDCl}_{3}\right) \delta$-76.6; HRMS $\left(\mathrm{FAB}^{+}, \mathrm{NBA}\right)$ calcd for $\mathrm{C}_{37} \mathrm{H}_{60} \mathrm{~F}_{3} \mathrm{~N}_{4} \mathrm{O}_{11} \mathrm{~S}(\mathrm{M}+\mathrm{H})^{+}$825.3931, found 825.3943 . 


\section{Solid-Phase Synthesis of Compounds 2-5}

The Rink resin was washed with DMF, and the $N^{\mathrm{a}}$-Fmoc protecting group was removed with 1:4 piperidine in DMF $(1 \times 2 \mathrm{~min}$ and $1 \times 20 \mathrm{~min})$. The resin was washed successively with DMF, $\mathrm{CH}_{2} \mathrm{Cl}_{2}$, and DMF. The next $N^{\mathrm{a}}$-Fmoc amino acid was coupled by using the HCTU/ $i-\operatorname{Pr}_{2}$ EtN procedure ( 3 equiv of $N^{a}$-Fmoc amino acid, 3 equiv of HCTU, and 3 equiv of $i-\operatorname{Pr}_{2} \mathrm{EtN} ; 1$ min preactivation) for $1 \mathrm{~h}$. The coupling procedure was repeated if the Kaiser test showed a purple color. If the second coupling did not result in a negative Kaiser test, the resin was washed with DMF and the free amino groups were capped with $50 \% \mathrm{Ac}_{2} \mathrm{O}$ in pyridine for $10 \mathrm{~min}$.

After coupling Val, Pro, Lys(Boc), Gly, Trp(Boc), Arg(Pbf), o-Phe, His(Trt), Glu(O- $t$-Bu), Nle, $\operatorname{Ser}(t-\mathrm{Bu}), \operatorname{Tyr}(t-\mathrm{Bu})$, and $\operatorname{Ser}(t-\mathrm{Bu})$ sequentially to the Rink amide resin, the dansylated PEG linker 17 was coupled as above. The trifluoroacetamide group was removed using a solution of hydrazine in MeOH/THF (15/15/70 v/v/v) for $6 \mathrm{~h}$. The resulting resin 21 was divided into two portions, one of which was acetylated to give 24. Assembly of the second NDP-a-MSH ligand was carried out on the second portion of resin 21 by the procedure described above to give $\mathbf{2 2}$. N-Terminal acetylation of $\mathbf{2 2}$ produced $\mathbf{2 3}$. Cleavage of the peptides $\mathbf{2}$ and $\mathbf{4}$ from the resins $\mathbf{2 3}$ and $\mathbf{2 4}$, respectively, with concomitant side-chain deprotection was effected using a cleavage cocktail ( $10 \mathrm{~mL}$ per $1 \mathrm{~g}$ of the resin) consisting of TFA (91\%), $\mathrm{H}_{2} \mathrm{O}(3 \%), \mathrm{HSCH}_{2}-\mathrm{CH}_{2} \mathrm{SH}(3 \%)$, and $\mathrm{PhSMe} \mathrm{(3 \% )} \mathrm{at} \mathrm{rt}$ for $3 \mathrm{~h}$. The solution was filtered off, the resin was washed with TFA $(2 \times 3 \mathrm{~min})$, the liquid phases were concentrated under a stream of nitrogen, and the product was precipitated using cold $\mathrm{Et}_{2} \mathrm{O}$. The product was washed three times with cold $\mathrm{Et}_{2} \mathrm{O}$, lyophilized, purified, and characterized (see the Supporting Information for methods and Table 1 for compound characterization data). Peptides $\mathbf{3}$ and $\mathbf{5}$ were synthesized, purified, and characterized similarly.

\section{Supplementary Material}

Refer to Web version on PubMed Central for supplementary material.

\section{Acknowledgments}

We sincerely thank Prof. Hironao Sajiki at the Gifu Pharmaceutical University for a gift of $5 \% \mathrm{Rh} / \mathrm{C}$. This work was supported by Grants R33 CA 95944, RO1 CA 97360, and P30 CA 23074 from the National Cancer Institute.

\section{References}

1. (a) Gillies RJ, Hoffman JM, Lam KS, Menkens AE, Piwnica-Worms DR, Sullivan DC, Weissleder R. Molecular Imaging. 2005; 4:98-103. [PubMed: 16105507] (b) Gillies RJ, Hruby VJ. Expert Opin. Ther. Targets. 2003; 7:137-139. [PubMed: 12667092]

2. Handl HL, Vagner J, Han H, Mash E, Hruby VJ, Gillies RJ. Expert Opin. Ther. Targets. 2004; 8:565-586. [PubMed: 15584863]

3. (a) Mammen M, Chio SK, Whitesides GM. Angew. Chem., Int. Ed. 1998; 37:2754-2794.(b) Kiessling LL, Gestwicki JE, Strong LE. Curr. Opin. Chem. Biol. 2000; 4:696-703. [PubMed: 11102876]

4. Tron L, Szollosi J, Szabo G Jr. Matyus L, Damjanovich S. Symp. Biol. Hung. 1984; 26:307-328. Small molecule dimensions are on the order of ten angstroms, while the distance between receptors is on the order of tens to hundreds of angstroms. See:

5. (a) Maison W, Frangioni JV, Pannier N. Org. Lett. 2004; 6:4567-4569. [PubMed: 15548077] (b) Monguchi Y, Vagner J, Handl HL, Jana U, Begay LJ, Hruby VJ, Gillies RJ, Mash EA. Tetrahedron Lett. 2005; 46:7589-7592.(c) Semetey V, Moustakas D, Whitesides GM. Angew. Chem., Int. Ed. 2006; 45:588-591.(d) Vagner J, Handl HL, Monguchi Y, Jana U, Begay LJ, Mash EA, Hruby VJ, Gillies RJ. Bioconjugate Chem. 2006; 17:1545-1550. 
6. (a) Vagner J, Handl HL, Gillies RJ, Hruby VJ. Bioorg. Med. Chem. Lett. 2004; 14:211-215. [PubMed: 14684330] (b) Raju N, Ranganathan RS, Tweedle MF, Swenson RE. Tetrahedron Lett. 2005; 46:1463-1465.

7. (a) Hashimoto M, Yang J, Holman GD. ChemBioChem. 2001; 2:52-59. [PubMed: 11828427] (b) Warnecke A, Kratz F. Bioconjugate Chem. 2003; 14:377-387.(c) Herforth C, Heidler P, Franke S, Link A. Bioorg. Med. Chem. 2004; 12:2895-2902. [PubMed: 15142550] (d) Jensen TW, Hu B-H, Delatore SM, Garcia AS, Messersmith PB, Miller WH. J. Am. Chem. Soc. 2004; 126:15223-15230. [PubMed: 15548019] (e) Warneke A, Fichtner I, Garmann D, Jaehde U, Kratz F. Bioconjugate Chem. 2004; 15:1349-1359.

8. Available from Quanta BioDesign, Ltd.

9. (a) Thumshirn G, Hersel U, Goodman SL, Kessler H. Chem. Eur. J. 2003; 9:2717-2725. The use of coupled lysine/poly(ethylene glycol) linkers has been reported; see. [PubMed: 12772286] (b) Song A, Wang X, Zhang J, Marík J, Lebrilla CB, Lam KS. Bioorg. Med. Chem. Lett. 2004; 14:161-165. [PubMed: 14684320]

10. (a) Sawyer TK, Sanfilippo PJ, Hruby VJ, Engel MH, Heward CB, Burnett JB, Hadley ME. Proc. Natl. Acad. Sci. U.S.A. 1980; 77:5754-5758. The "high-affinity" ligand employed here was based on NDP-a-MSH (Ser-Tyr-Ser-Nle-Glu-His-d-Phe-Arg-Trp-Gly-Lys-Pro-Val); see: [PubMed: 6777774] (b) Hadley ME, Anderson B, Heward CB, Sawyer TK, Hruby VJ. Science. 1981; 213:1025-1027. The "low-affinity" ligand employed was based on the minimal active sequence for full agonist activity of a-MSH (His-d-Phe-Arg-Trp). [PubMed: 6973820] (c) Hruby VJ, Wilkes BC, Hadley ME, Al-Obeidi F, Sawyer TK, Staples DJ, DeVaux AE, Dym O, de L. Castrucci AM, Hintz MF, Riehm JP, Rao KR. J. Med. Chem. 1987; 30:2126-2130. see: [PubMed: 2822931] (d) de Lauro Castrucci AM, Hadley ME, Sawyer TK, Wilkes BC, Al-Obiedi F, Staples DJ, DeVaux AE, Dym O, Hintz MF, Riehm JP, Rao KR, Hruby VJ. Gen. Comp. Endocrinol. 1989; 73:157-163. [PubMed: 2537778] (e) Haskell-Luevano C, Hendrata S, North C, Sawyer TK, Hadley ME, Hruby VJ, Dickinson C, Gantz I. J. Med. Chem. 1997; 40:2133-2139. [PubMed: 9216831]

11. (a) Bendavid A, Burns CJ, Field LD, Hashimoto K, Ridley DD, Sandanayake KRAS, Wieczorek L. J. Org. Chem. 2001; 66:3709-3716. [PubMed: 11374989] (b) Zhang W, Nowlan DT III, Thomson LM, Lackowski WM, Simanek EE. J. Am. Chem. Soc. 2001; 123:8914-8922. [PubMed: 11552798] (c) McReynolds KD, Bhat A, Conboy JC, Saavedra SS, Gervay-Hague J. Bioorg. Med. Chem. 2002; 10:625-637. [PubMed: 11814851]

12. (a) Atkins MP, Golding BT, Howes DA, Sellars PJ. J. Chem. Soc., Chem. Commun. 1980:207208.(b) Corey EJ, Kyler K, Raju N. Tetrahedron Lett. 1984; 25:5115-5118.(c) Baldwin JE, Adlington RM, Robertson J. Tetrahedron. 1991; 47:6795-6812.

13. Sajiki H, Ikawa T, Hirota K. Org. Lett. 2004; 6:4977-4980. [PubMed: 15606114]

14. Aavula BR, Ali MA, Mash EA, Bednarczyk D, Wright SH. Synth. Commun. 2006; 36:701-705.

15. (a) Merrifield RB. J. Am. Chem. Soc. 1963; 85:2149-2154.(b) Hruby, VJ.; Meyer, J-P. Bioorganic Chemistry: Peptides and Proteins. Hecht, SM., editor. Oxford University Press; New York: 1998. p. 27-64.

16. Handl HL, Vagner J, Yamamura HI, Hruby VJ, Gillies RJ. Anal. Biochem. 2004; 330:242-250. [PubMed: 15203329]

17. Gantz I, Miwa H, Konda Y, Shimoto Y, Tashiro T, Watson SJ, DelValle J, Yamada T. J. Biol. Chem. 1993; 268:15174-15179. The hMC4R vector was originally received from Dr. Ira Gantz; see: [PubMed: 8392067] 

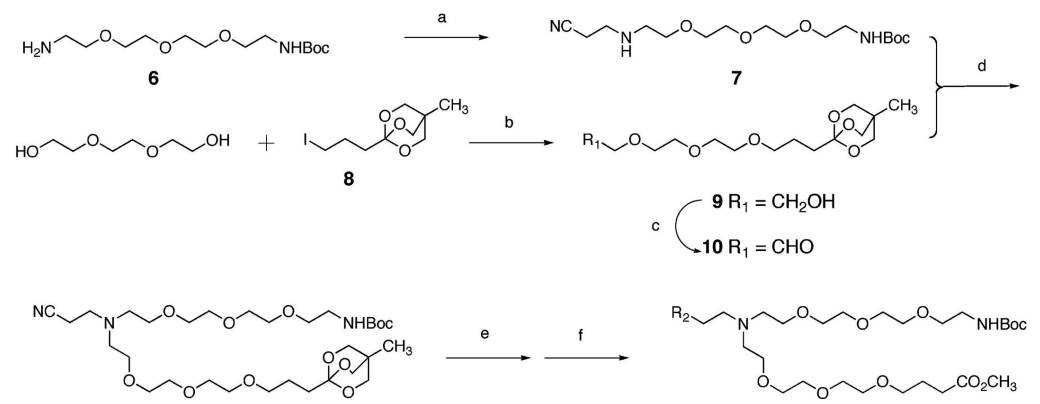

11
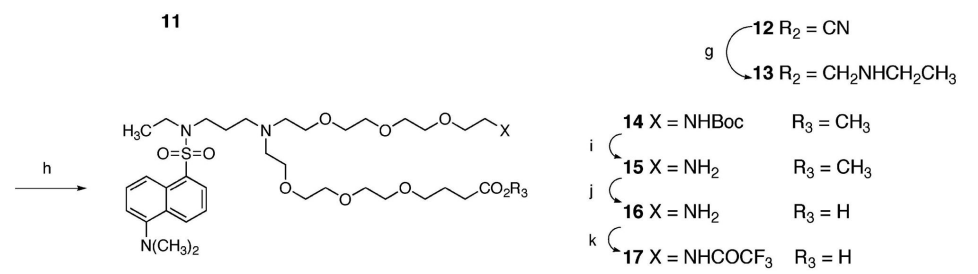

Scheme 1. Synthesis of Compound $17^{a}$

${ }^{a}$ Reagents and conditions: (a) acrylonitrile, $\mathrm{CH}_{3} \mathrm{OH}$; (b) NaH, THF; (c) DMSO, $(\mathrm{COCl})_{2}$, $\mathrm{Et}_{3} \mathrm{~N}, \mathrm{CH}_{2} \mathrm{Cl}_{2}$; (d) $\mathrm{NaBH}(\mathrm{OAc})_{3}, \mathrm{ClCH}_{2} \mathrm{CH}_{2} \mathrm{Cl}$; (e) $\mathrm{TsOH}$, aq $\mathrm{CH}_{3} \mathrm{OH}$; (f) $\mathrm{K}_{2} \mathrm{CO}_{3}, \mathrm{CH}_{3} \mathrm{OH}$; (g) $\mathrm{H}_{2}, \mathrm{Rh} / \mathrm{C}, \mathrm{EtNH}_{2}, \mathrm{CH}_{3} \mathrm{OH}$; (h) dansyl chloride, $\mathrm{Et}_{3} \mathrm{~N}, \mathrm{CH}_{2} \mathrm{Cl}_{2}$; (i) $\mathrm{HCl}, \mathrm{Et}_{2} \mathrm{O}$, EtOAc, $\mathrm{CH}_{3} \mathrm{OH}$; (j) $\mathrm{NaOH}$, aq $\mathrm{CH}_{3} \mathrm{OH}$, THF; (k) $\mathrm{CF}_{3} \mathrm{CO}_{2} \mathrm{Et}, \mathrm{CH}_{3} \mathrm{OH}, \mathrm{Et}_{3} \mathrm{~N}$. 


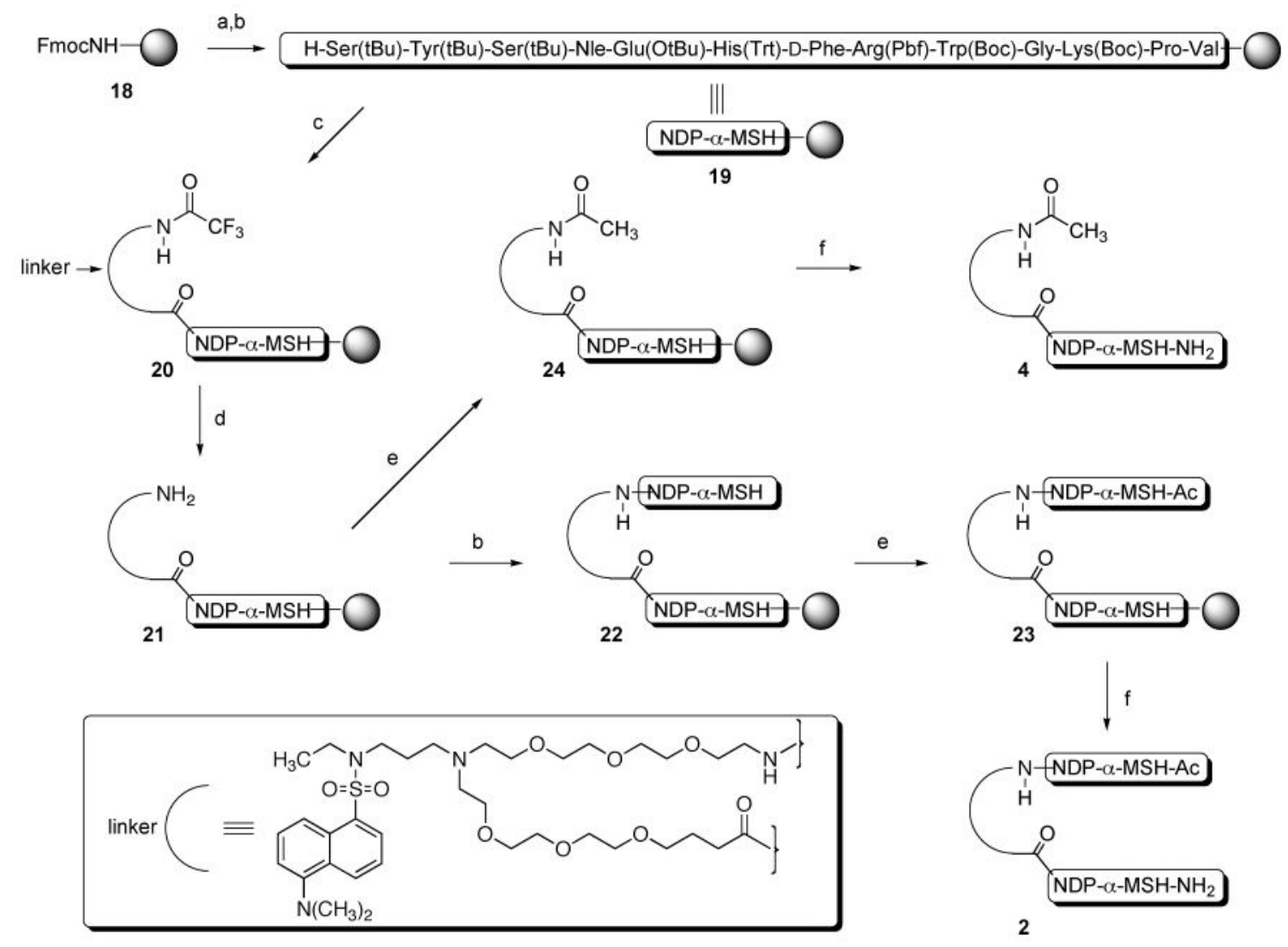

Scheme 2. Solid-Phase Synthesis of Compounds 2 and $4^{a}$

${ }^{a}$ Reagents and conditions: (a) piperidine; (b) Fmoc/t-Bu solid-phase synthesis (ref 15); (c) N-protected linker, HCTU, $i$ - $\mathrm{Pr}_{2} \mathrm{EtN}$, DMF; (d) THF/MeOH/ $\mathrm{N}_{2} \mathrm{H}_{4}$ (70/15/15); (e) pyridine/ $\mathrm{Ac}_{2} \mathrm{O}$ (90/10); (f) TFA/HSCH${ }_{2} \mathrm{CH}_{2} \mathrm{SH} / \mathrm{PhSMe} / \mathrm{H}_{2} \mathrm{O}(91 / 3 / 3 / 3)$. 
TABLE 2

Competitive Binding of NDP-a-MSH, MSH(4), and Compounds 2-5 to hMC4R ${ }^{a}$

\begin{tabular}{lcc}
\hline compd & IC $_{\mathbf{5 0}}$ & $\boldsymbol{n}$ \\
\hline NDP-a-MSH & $5.86 \pm 1.90 \mathrm{nM}$ & 5 \\
$\mathbf{2}$ & $1.45 \pm 0.44 \mathrm{nM}$ & 6 \\
$\mathbf{4}$ & $3.62 \pm 0.86 \mathrm{nM}$ & 6 \\
$\mathrm{MSH}(4)$ & $1.15 \pm 0.53 \mu \mathrm{M}$ & 4 \\
$\mathbf{3}$ & $0.37 \pm 0.12 \mu \mathrm{M}$ & 6 \\
$\mathbf{5}$ & $0.42 \pm 0.22 \mu \mathrm{M}$ & 6 \\
\hline
\end{tabular}

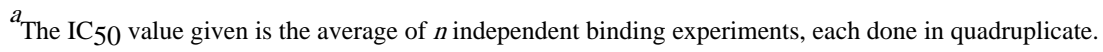

